\title{
Deep Dive Into Familial Mediterranean Fever in a Child Without Fever
}

Vikash Jaiswal ${ }^{1}$, Zouina Sarfraz ${ }^{2}$, Trissa Paul ${ }^{3}$, Furqan Ahmad Jarullah ${ }^{4}$, Christine Zakhary ${ }^{5}$

1. Internal Medicine, AMA School of Medicine, Makati, PHL 2. Internal Medicine, Fatima Jinnah Medical University, Lahore, PAK 3. Internal Medicine, Avalon University School of Medicine, Ohio, USA 4. Medicine, Jinnah Medical and Dental College, Karachi, PAK 5. Internal Medicine, Ain Shams General Hospital, Cairo, EGY

Corresponding author: Zouina Sarfraz , zouinasarfraz@gmail.com

\begin{abstract}
This case report entails the details of a 12-year-old Egyptian boy who had recurrent episodes of shortness of breath, ascites, and pericardial effusions starting at the age of 10 , returning with worsening symptoms in April of 2020. The lab findings indicated a critically elevated C-reactive protein (CRP) of $107.2 \mathrm{mg} / \mathrm{L}$; a clinically notable inflammation process was festering. This case was all the more interesting as this boy did not present with a fever, making the diagnosis a difficult one. Nonetheless, genetic Mediterranean fever (MEFv) and polymerase chain reaction (PCR) testing confirmed the diagnosis of familial MEFv. Steroids and colchicine-salicylate decreased the frequency of the attacks and are now on half a dose of colchicine to keep his symptoms at bay. What we see here is the risk-to-benefit ratio of the therapeutic use of colchicine in children outweighs potential side effects such as nausea, vomiting, abdominal pain, diarrhea, kidney or liver failure. However, further research is needed to access better long-term treatment plans. Another key takeaway point that can be highlighted in this case is that the patient does not need to be febrile to diagnose FMF.
\end{abstract}

Categories: Genetics, Internal Medicine

Keywords: familial mediterranean fever, infection, colchicine, rare genetic diseases, autoinflammatory disease

\section{Introduction}

Familial Mediterranean fever (FMF) is an inherited autoinflammatory disorder characterized by recurrent episodes of fever, peritonitis, arthritis, pleuritis, and rash [1]. Some long-term complications of FMF include systemic amyloidosis and renal impairment [2]. FMF typically occurs in individuals of Mediterranean origin, but it may affect people of any ethnicity [3]. Patients usually present with inflammatory attacks before the age of 20 , and symptoms persist for three days or less before they are spontaneously resolved [1,4]. The Mediterranean fever (MEFv) gene encodes for the Pyrin protein, which regulates inflammation and innate immunity [4]. The diagnosis of FMF is predominantly clinical and may be confirmed by MEFv gene mutation analysis [5]. Colchicine is the gold standard treatment of FMF that prevents recurrent seizures and is protective against the development of renal amyloidosis due to MEFv gene mutations [6]. In recent years, clinical management options of FMF have expanded, but data of Egyptian descent remain limited. In this report, an emphasis is placed on the clinical presentation and management of a 12-year-old male patient who had an afebrile presentation with MEFv gene mutation.

\section{Case Presentation}

A 12-year-old Egyptian male patient presented to the outpatient department with complaints of shortness use, distribution, and reproduction in any of breath. On general physical examination, distant heart sounds and abdominal ascites were noted. A medium, provided the originat author and source are credited. hemoglobin level of $10.6 \mathrm{~g} / \mathrm{dL}$ indicating anemia was noted on laboratory testing, and he was admitted as an inpatient.

The echocardiogram revealed significant circumferential pericardial effusion, with no echocardiographic signs of cardiac tamponade. Thickening of the bilateral visceral and parietal pericardium was seen along with a shaggy appearing pericardial space and fibrinous threads all over, represented by maximal posterior dimensions measuring $1 \mathrm{~cm}$ and anterior dimensions measuring $0.5 \mathrm{~cm}$ in width. Other abnormalities on the echocardiogram were consistent with bilateral atrial enlargement, accompanied by a mild grade 1 diastolic dysfunction.

After these findings were noted, a pericardiocentesis was performed. The hematology report showed low hematocrit (HCT=35.2\%), mean corpuscular hemoglobin ( $\mathrm{MCH}=23.7 \mathrm{pg} / \mathrm{cell})$, and elevated levels of red cel distribution width (RDW=15.7\%). These levels were borderline normal.

A pleural fluid test was conducted to identify the cause of the pleural effusion. The pleural culture revealed a yellowish, turbid specimen with moderate amounts of pus on gram stain and lymphocytes on Leishman stain. The pericardial culture revealed a few pus cells on gram staining, however, the results were otherwise unremarkable. This patient's sodium level was low $(\mathrm{Na}=136 \mathrm{mmol} / \mathrm{L})$ and the $\mathrm{C}$-reactive protein $(\mathrm{CRP}=107.2$ $\mathrm{mg} / \mathrm{L}$ ) was critically elevated consistent with severe inflammation.

The patient was put on a steroid treatment of prednisolone $20 \mathrm{mg}$, three times a day, on which improvement was noted and the patient was discharged. After he was tapered off of the steroid treatment he returned to the hospital six months post-initial presentation with similar symptoms, namely pericardial effusion and ascites.

The MEFv genetic mutation was positive, which is the gold standard test for FMF. A polymerase chain reaction (PCR) test was done to confirm the diagnosis of FMF, which returned positive as well. Colchicine 1 $\mathrm{mg}$, an anti-inflammatory drug, was commenced daily to which the patient responded with dramatic 


\section{Cureus}

improvement.

There was no presence of family FMF history; however, the response to colchicine, radiological and laboratory results aided in the workup at the onset. Because FMF mainly affects the people of Mediterranean and Middle Eastern origin, it is essential to note that the afebrile presentation was primarily supported by response to therapy and was corroborated by MEFv gene confirmation.

One year post initial presentation to the outpatient department, the patient was being administered with colchicine $0.5 \mathrm{mg}$ daily, which kept his symptoms subsided. Echocardiogram and ultrasound tests were conducted once a month to monitor the patient's condition. On the last follow-up, the patient was progressing well, with no abnormal signs.

\section{Discussion}

In addition to the 12-year-old boy's case, we conducted a literature review of $23 \mathrm{FMF}$ cases (Table 1). Of the 23 reported cases, 11 originated from Turkey, three from Italy, and one each from Armenia, Colombia, Germany, Iran, Israel, Japan, Morocco, and Pakistan. When noting the FMF criteria, gene mutations were noted in all the listed cases, with nine heterozygous MEFv gene mutations, six homozygous mutations, and seven otherwise unspecified MEFv gene mutations. The most commonly reported clinical manifestations of disease included fever, abdominal pain, bloody or mucous diarrhea, diffuse myalgia, and rashes. On documenting the family history, eight of the 23 studies confirmed a positive family history with a sibling, parent, or the first-degree relative diagnosed with FMF or being heterozygous/homozygous for the same mutation. The laboratory values suggested a rise in serum amyloid A (SAA) of the included cases, in addition to elevated CRP, ESR, ALT, and AST levels. The most common treatment option was colchicine, given its importance as the gold standard treatment. However, the inclusion of recent reports (2016-2021) led to the identification of cases with biologics and chemotherapeutic drugs being prescribed with documented recovery among patients.

\begin{tabular}{|c|c|c|c|c|c|c|c|c|c|c|c|}
\hline No & Author & Title & Country & Age & Gender & FMF criteria & $\begin{array}{l}\text { Clinical } \\
\text { Manifestations }\end{array}$ & $\begin{array}{l}\text { Family } \\
\text { History }\end{array}$ & Lab Values & Intervention & 1 \\
\hline 1 & Maggio et al. & $\begin{array}{l}\text { Familial } \\
\text { Mediterranean } \\
\text { fever: an unusual } \\
\text { cause of liver } \\
\text { disease }\end{array}$ & Italy & $\begin{array}{l}10.6 \\
\text { years }\end{array}$ & Male & $\begin{array}{l}\text { Homozygous } \\
\text { MEFv gene } \\
\text { mutation }\end{array}$ & $\begin{array}{l}\text { Recurrent fever, } \\
\text { aphthous } \\
\text { stomatitis, rash, } \\
\text { arthralgia, } \\
\text { associated with } \\
\text { abdominal pain, } \\
\text { vomiting, } \\
\text { lymphadenopathy }\end{array}$ & N/A & $\begin{array}{l}\mathrm{SAA}=33 \mathrm{mg} / \mathrm{L}, \\
\mathrm{CRP}=24.8 \mathrm{mg} / \mathrm{dL} \text {, } \\
\mathrm{ESR}=86, \mathrm{AST} \text { and } \\
\text { ALT were } \\
\text { elevated }\end{array}$ & Colchicine & 1 \\
\hline 2 & Atmış et al. & $\begin{array}{l}\text { Concomitance of } \\
\text { familial } \\
\text { Mediterranean } \\
\text { fever and Gitelman } \\
\text { syndrome in an } \\
\text { adolescent }\end{array}$ & Turkey & 9 years & Male & $\begin{array}{l}\text { Homozygous } \\
\text { MEFv gene } \\
\text { mutation }\end{array}$ & $\begin{array}{l}\text { Recurrent } \\
\text { abdominal pain, } \\
\text { fever, joint pain, } \\
\text { and swelling for } 3 \\
\text { years }\end{array}$ & $\begin{array}{l}\text { The patient } \\
\text { has one } \\
\text { sibling and } \\
\text { was } \\
\text { diagnosed } \\
\text { with FMF } \\
\text { homozygous } \\
\text { M694V }\end{array}$ & $\begin{array}{l}\text { Hypokalemıa, } \\
\text { hyponatremia, } \\
\text { hypomagnesemia }\end{array}$ & Colchicine & 1 \\
\hline 3 & $\begin{array}{l}\text { Javascript et } \\
\text { al. }\end{array}$ & $\begin{array}{l}\text { Tofacitinib for } \\
\text { familial } \\
\text { Mediterranean } \\
\text { fever: a new } \\
\text { alternative } \\
\text { therapy? }\end{array}$ & Colombia & 16 years & Male & $\begin{array}{l}\text { Heterozygous } \\
\text { MEFv gene } \\
\text { mutation }\end{array}$ & $\begin{array}{l}\text { Recurrent fevers, } \\
\text { cutaneous rash, } \\
\text { and recurrent } \\
\text { abdominal pain } \\
\text { with diarrhea }\end{array}$ & N/A & $\mathrm{N} / \mathrm{A}$ & Tofacitinib & 1 \\
\hline 4 & Yasuda et al. & $\begin{array}{l}\text { Canakinumab } \\
\text { Eliminates } \\
\text { Resistant Familial } \\
\text { Mediterranean } \\
\text { Fever in a } \\
\text { Japanese Girl }\end{array}$ & Japan & 7 years & Girl & $\begin{array}{l}\text { Heterozygous } \\
\text { MEFv gene } \\
\text { mutation }\end{array}$ & $\begin{array}{l}\text { Recurrent febrile } \\
\text { attacks including } \\
\text { abdominal pain } \\
\text { lasting } 2-3 \text { days }\end{array}$ & N/A & Elevated CRP & Canakinumab & 1 \\
\hline 5 & Yıldırım et al. & $\begin{array}{l}\text { Protracted febrile } \\
\text { myalgia as a } \\
\text { challenging } \\
\text { manifestation of } \\
\text { familial } \\
\text { Mediterranean } \\
\text { fever: case-based } \\
\text { review }\end{array}$ & Turkey & $\begin{array}{l}\text { Median }=6 \\
\text { years }\end{array}$ & $\begin{array}{l}3 \\
2 \text { Female }\end{array}$ & $\begin{array}{l}\text { MEFv gene } \\
\text { mutation }\end{array}$ & $\begin{array}{l}\text { Severe myalgia, } \\
\text { fever, abdominal } \\
\text { pain, diarrhea, } \\
\text { and } \\
\text { arthralgia/arthritis }\end{array}$ & N/A & N/A & $\begin{array}{l}\text { Corticosteroids, } \\
\text { NSAIDs, anakinra, } \\
\text { anti-interleukin-1 }\end{array}$ & $\begin{array}{l}1 \\
\vdots \\
1 \\
1\end{array}$ \\
\hline 6 & Gökçe et al. & $\begin{array}{l}\text { Polyarteritis } \\
\text { nodosa in case of } \\
\text { familial }\end{array}$ & Turkey & 14 years & Male & $\begin{array}{l}\text { Homozygous } \\
\text { MEFv gene }\end{array}$ & $\begin{array}{l}\text { Fever, diffuse } \\
\text { myalgia, } \\
\text { abdominal pain, }\end{array}$ & N/A & $\begin{array}{l}\text { Leukocytosis, } \\
\text { normal platelets, } \\
\text { hemoglobin } 13.3 \\
\text { normal urea and } \\
\text { creatinine ESR } 93\end{array}$ & $\begin{array}{l}\text { Prednisolone, } \\
\text { azathioprine, }\end{array}$ & I \\
\hline
\end{tabular}




\section{Cureus}

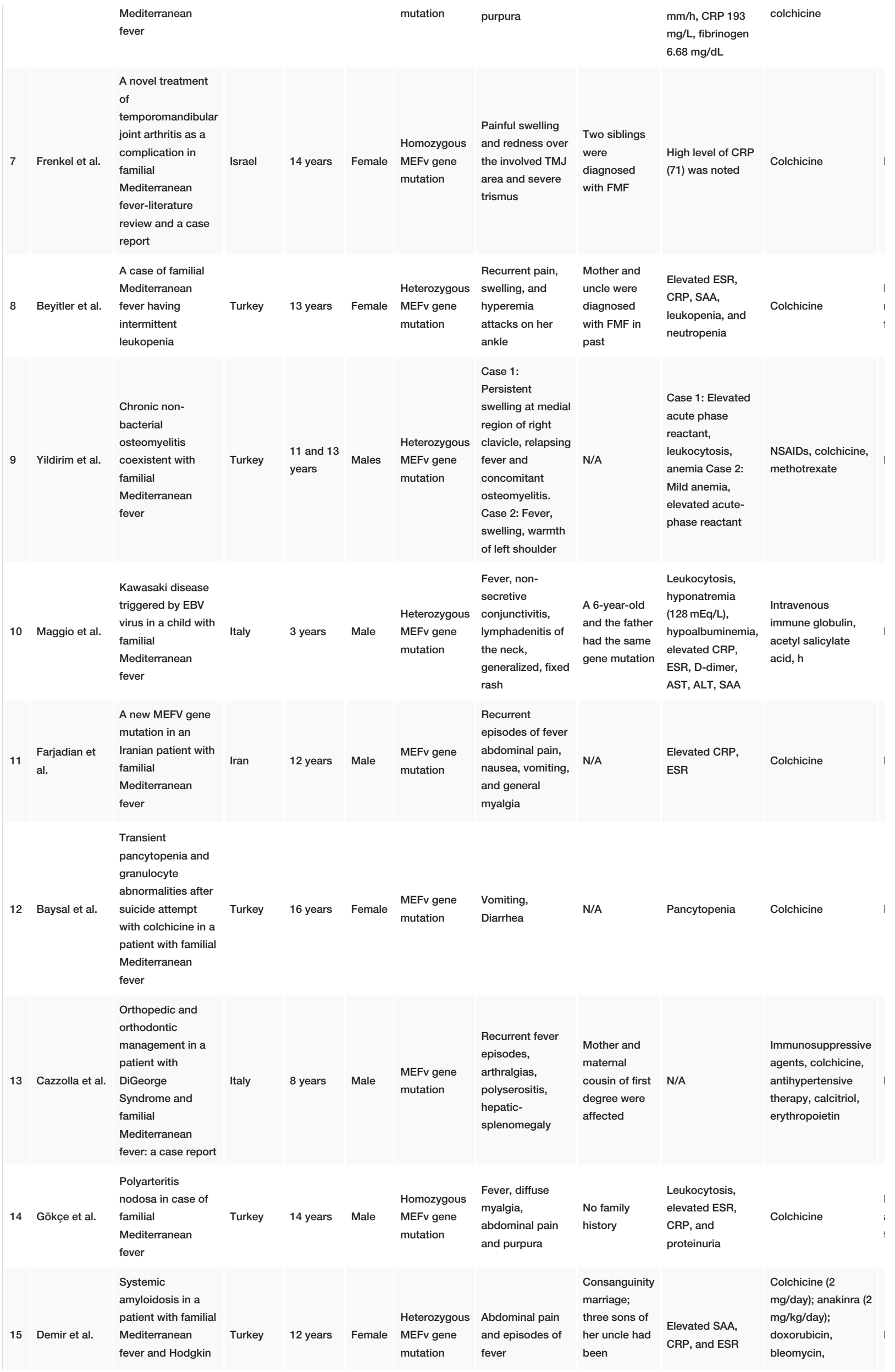




\section{Cureus}

\begin{tabular}{|c|c|c|c|c|c|c|c|c|c|c|c|}
\hline & & $\begin{array}{l}\text { lymphoma: a case } \\
\text { report }\end{array}$ & & & & & & $\begin{array}{l}\text { diagnosed } \\
\text { with FMF }\end{array}$ & & $\begin{array}{l}\text { vinblastine, and } \\
\text { dacarbazine (ABVD) }\end{array}$ & \\
\hline 16 & $\begin{array}{l}\text { Aydoğdu et } \\
\text { al. }\end{array}$ & $\begin{array}{l}\text { An extraordinary } \\
\text { complication in a } \\
\text { child with } \\
\text { combined familial } \\
\text { Mediterranean } \\
\text { fever and } \\
\text { inflammatory bowel } \\
\text { disease: multiple } \\
\text { ileal perforations }\end{array}$ & Turkey & 5 years & Female & $\begin{array}{l}\text { Heterozygous } \\
\text { MEFv gene } \\
\text { mutation }\end{array}$ & $\begin{array}{l}\text { Fever, abdominal } \\
\text { pain, vomiting }\end{array}$ & N/A & $\begin{array}{l}\text { Elevated CRP and } \\
\text { ESR }\end{array}$ & $\begin{array}{l}\text { Colchicine, oral } \\
\text { steroids, } \\
\text { canakinumab, } \\
\text { anakinra, infliximab }\end{array}$ & 1 \\
\hline 17 & Sag et al. & $\begin{array}{l}\text { Neonatal ulcerative } \\
\text { colitis associated } \\
\text { with familial } \\
\text { Mediterranean } \\
\text { fever: a case report }\end{array}$ & Germany & 3 months & Female & $\begin{array}{l}\text { Homozygous } \\
\text { MEFv gene } \\
\text { mutation }\end{array}$ & $\begin{array}{l}\text { Bloody and } \\
\text { mucous diarrhea, } \\
\text { two episodes of } \\
\text { high fever }\end{array}$ & N/A & Elevated CRP & Colchicine & 1 \\
\hline 18 & Ceylan et al. & $\begin{array}{l}\text { Intermittent right } \\
\text { bundle branch } \\
\text { block in a child with } \\
\text { familial } \\
\text { Mediterranean } \\
\text { fever }\end{array}$ & Turkey & 8 years & Male & $\begin{array}{l}\text { Heterozygous } \\
\text { MEFv gene } \\
\text { mutation }\end{array}$ & N/A & N/A & $\begin{array}{l}\text { Elevated } \\
\text { Inflammatory } \\
\text { biomarkers. } \\
\text { RBBB could be } \\
\text { associated with } \\
\text { FMF or Colchicine }\end{array}$ & Colchicine & 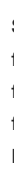 \\
\hline 19 & Zerkaoui et al. & $\begin{array}{l}\text { A novel single } \\
\text { variant in the MEFV } \\
\text { gene causing } \\
\text { Mediterranean } \\
\text { fever and Behçet's } \\
\text { disease: a case } \\
\text { report }\end{array}$ & Morocco & 10 years & Female & $\begin{array}{l}\text { MEFv gene } \\
\text { mutation }\end{array}$ & $\begin{array}{l}\text { Periodic fever, } \\
\text { abdominal pain, } \\
\text { mucocutaneous } \\
\text { symptoms, and } \\
\text { joint pain }\end{array}$ & $\begin{array}{l}\text { The mother } \\
\text { was normal, } \\
\text { and her father } \\
\text { was } \\
\text { heterozygous } \\
\text { for the same } \\
\text { mutation }\end{array}$ & Elevated CRP & $\begin{array}{l}\text { Colchicine, } \\
\text { methylprednisolone, } \\
\text { opioids, intravenous } \\
\text { anticoagulation for } \\
\text { sinus thrombosis }\end{array}$ & I \\
\hline 20 & Yoldas et al. & $\begin{array}{l}\text { Massive pericardial } \\
\text { effusion and } \\
\text { tamponade can be } \\
\text { a first sign of } \\
\text { familial } \\
\text { Mediterranean } \\
\text { fever }\end{array}$ & Turkey & $\begin{array}{l}10 \text { and } 13 \\
\text { years }\end{array}$ & $\begin{array}{l}\text { Male, } \\
\text { Female }\end{array}$ & $\begin{array}{l}\text { Heterozygous } \\
\text { MEFv gene } \\
\text { mutation }\end{array}$ & $\begin{array}{l}\text { Chest pain, } \\
\text { dyspnea, and } \\
\text { fever }\end{array}$ & N/A & $\begin{array}{l}\text { Elevated ESR, } \\
\text { CRP }\end{array}$ & Colchicine & 1 \\
\hline 21 & $\begin{array}{l}\text { Shahsuvaryan } \\
\text { et al. }\end{array}$ & $\begin{array}{l}\text { Is plasmapheresis } \\
\text { a potential } \\
\text { treatment for } \\
\text { familial } \\
\text { Mediterranean } \\
\text { fever patients } \\
\text { resistant or } \\
\text { intolerant to } \\
\text { colchicine? }\end{array}$ & Armenia & 17 years & Female & $\begin{array}{l}\text { MEFv gene } \\
\text { mutation }\end{array}$ & $\begin{array}{l}\text { Recurrent attacks } \\
\text { of fever and } \\
\text { abdominal pain }\end{array}$ & N/A & $\begin{array}{l}\text { Elevated ESR and } \\
\text { CRP }\end{array}$ & Colchicine & I \\
\hline 22 & Maggio et al. & $\begin{array}{l}\text { PAPA and FMF in } \\
\text { two siblings: } \\
\text { possible } \\
\text { amplification of } \\
\text { clinical } \\
\text { presentation? A } \\
\text { case report }\end{array}$ & Italy & $\begin{array}{l}8.4 \text { and } \\
16 \text { years }\end{array}$ & Male & $\begin{array}{l}\text { Homozygous } \\
\text { MEFv gene } \\
\text { mutation }\end{array}$ & $\begin{array}{l}\text { Fever, oral } \\
\text { aphthous } \\
\text { stomatitis, } \\
\text { abdominal pain, } \\
\text { arthritis, } \\
\text { undefined } \\
\text { dermatitis, } \\
\text { vomiting, } \\
\text { diarrhea }\end{array}$ & $\begin{array}{l}\text { Both parents } \\
\text { were } \\
\text { heterozygous } \\
\text { for the same } \\
\text { mutation } \\
\text { p.M680I }\end{array}$ & $\begin{array}{l}\text { Elevated AST, } \\
\text { ALT, CRP, ESR, } \\
\text { SAA, leukocytosis } \\
\text { with neutrophilia }\end{array}$ & Colchicine & 1 \\
\hline 23 & Hong et al. & $\begin{array}{l}\text { Autoinflammation } \\
\text { due to homozygous } \\
\text { S208 MEFV } \\
\text { mutation }\end{array}$ & Pakistan & $\begin{array}{l}9 \text { and } 12 \\
\text { years }\end{array}$ & Male & $\begin{array}{l}\text { MEFv gene } \\
\text { mutation }\end{array}$ & $\begin{array}{l}\text { Recurrent fever, } \\
\text { oral ulceration, } \\
\text { purpuric rashes, } \\
\text { arthralgia, } \\
\text { eosinophilia, and } \\
\text { osteitis }\end{array}$ & $\begin{array}{l}\text { No family } \\
\text { history of } \\
\text { genetic } \\
\text { testing }\end{array}$ & $\begin{array}{l}\text { Elevated SAA, } \\
\text { CRP, and } \\
\text { leukocytosis }\end{array}$ & $\begin{array}{l}\text { Lipopolysaccharide, } \\
\text { IL-1 blockade }\end{array}$ & I \\
\hline
\end{tabular}

TABLE 1: Characteristics of study findings of cases reported from 2016-2021.

$\mathrm{ALT}=$ alanine transaminase; $\mathrm{AST}=$ aspartate aminotransferase; $\mathrm{CRP}=\mathrm{C}$-reactive protein; $\mathrm{ESR}=$ erythrocyte sedimentation rate; $\mathrm{N} / \mathrm{A}=$ not available; RBBB=right bundle branch block; SAA=Serum amyloid $A$.

The striking feature of our case presentation is the fact that the young male patient did not present with fever, similar to findings observed by Hotta and Mattiassich et al. [7,8]. Cekin and Aslan et al. [9,10] had identical complaints to our patient comprising abdominal ascites. Aslan et al. [10], however, did not note 
abdominal pain, which was identified by Tatar and Lee et al. [11,12], but without distention secondary to ascites. Incidentally, it was discovered soon after the initial workup that our patient also had added heart sounds, who was later diagnosed to have pericardial effusion. Abukhalaf and Ceylan et al. $[13,14]$ also reported cardiac complications among their patients, namely cardiac amyloidosis and right bundle branch block, respectively.

Despite the differences in age groups, clinical presentations, family history, or laboratory results, colchicine remains the first-line treatment modality for a majority of the tabulated patients, with documented recovery. However, Ceylan et al. point out an unprecedented view of FMF, where colchicine may exacerbate pre-existing cardiac conditions [14]. Even though the presentation was an isolated incident, it is pivotal to monitor colchicine during and post-administration on a regular basis. When identifying clinical practice points highlighted with our case and subsequent tabulation of recent trends in treatment, it is pertinent to note the European League Against Rheumatism (EULAR) recommendations for FMF management supported by the best evidence available [15]. As with EULAR recommendations, the best management strategy for FMF is to control acute attacks, minimize any chronic subclinical inflammation, improve the acceptable quality of life, and prevent recurring complications.

While FMF is mostly a clinical diagnosis, laboratory analysis may reveal elevated white blood cell count with peaked neutrophil. An elevation of acute-phase reactants, such as erythrocyte sedimentation rate (ESR), SAA, and CRP, is not uncommon. Radiological testing may be utilized to reveal other causes of abdominal pain, such as the acute abdomen. Gene mutation testing may be utilized to confirm the diagnosis with atypical presentations, particularly in non-endemic areas.

Overall, a central challenge for interprofessional healthcare teams managing FMF is to reach a diagnostic conclusion. Education about the etiology, family history, and testing options, in addition to associating typical or atypical clinical presentations to FMF, is necessary. Once the diagnosis is established, the clinician, nurse, and other providers ought to work closely. The use of colchicine, in addition to biologics and chemotherapeutic drugs along with noting the normal or abnormal clinical presentation, is essential in any clinical setting.

\section{Conclusions}

FMF is the most common autoinflammatory disease. The usual presentation of FMF in patients is fever; but in this case, the patient was afebrile whereas the diagnosis was confirmed on PCR testing. Colchicine, which has been the prescribed treatment for FMF since 1972, has shown a promising impact on patient conditions and is currently the first-line treatment for management. Further research is needed to access better longterm treatment plans such as the use of biologics namely anti-interleukin 1, anti-interleukin 6, Janus kinase inhibitors, and anti-TNF drugs. It is recommended that colchicine-resistant and intolerant cases be monitored for certain cytokines, along with genetic studies to improve clinical outcomes and compliance to treatment in endemic countries.

\section{Additional Information \\ Disclosures}

Human subjects: Consent was obtained or waived by all participants in this study. Fatima Jinnah Medical University issued approval Not applicable. The patient signed an informed consent form as per the ethical guidelines of the hospital board. Conflicts of interest: In compliance with the ICMJE uniform disclosure form, all authors declare the following: Payment/services info: All authors have declared that no financial support was received from any organization for the submitted work. Financial relationships: All authors have declared that they have no financial relationships at present or within the previous three years with any organizations that might have an interest in the submitted work. Other relationships: All authors have declared that there are no other relationships or activities that could appear to have influenced the submitted work.

\section{References}

1. Simon A, van der Meer JW, Drenth JP: Familial Mediterranean fever--a not so unusual cause of abdominal pain. Best Pract Res Clin Gastroenterol. 2005, 19:199-213. 10.1016/.jbpg.2004.11.009

2. Kastner DL: Familial Mediterranean fever: the genetics of inflammation . Hosp Pract (1995). 1998, 33:131-4, 139-40, 143-6 passim. 10.3810/hp.1998.04.90

3. Ben-Chetrit E, Touitou I: Familial mediterranean fever in the world . Arthritis Rheum. 2009, 61:1447-53. $10.1002 /$ art. 24458

4. Mansour AR, El-Shayeb A, El Habachi N, et al.: Molecular patterns of MEFV gene mutations in Egyptian patients with familial Mediterranean fever: a retrospective cohort study. Int J Inflam. 2019, 2019:2578760. $10.1155 / 2019 / 2578760$

5. Bonyadi M, Esmaeili M, Karimi A, Dastgiri S: Common Mediterranean fever gene mutations in the Azeri Turkish population of Iran. Genet Test Mol Biomarkers. 2010, 14:149-51. 10.1089/gtmb.2009.0087

6. Fietta P: Autoinflammatory diseases: the hereditary periodic fever syndromes . Acta Biomed. 2004, 75:92-9.

7. Hotta Y, Kawasaki T, Kotani T, et al.: Familial mediterranean fever without fever. Intern Med. 2020, 59:1267-70. 10.2169/internalmedicine.3175-19

8. Mattiassich G, Semlitsch G, Nadler K, Rainer F: Familial Mediterranean fever without fever as a cause of monoarthritis. BMJ Case Rep. 2013, 2013:bcr2012008395. 10.1136/bcr-2012-008395

9. Cekin AH, Dalbudak N, Künefeci G, et al.: Familial mediterranean fever with massive recurrent ascites: a case report. Turk J Gastroenterol. 2003, 14:276-9.

10. Aslan M, Demir G, Esen R, et al.: A rare cause of massive ascites: familial Mediterranean fever . Turk J Gastroenterol. 2012, 23:290-3. 10.4318/tig.2012.0374

11. Tatar E, Uslu A, Simsek C, Aykas A, Bozkaya G, Imamoglu C: Late diagnosis of E148Q mutation-positive familial mediterranean fever in a kidney transplant patient with fever of unknown origin: a case report. Exp Clin Transplant. 2017, 15:261-4. 10.6002/ect.mesot2016.P131

12. Lee CG, Lim YJ, Kang HW, et al.: A case of recurrent abdominal pain with fever and urticarial eruption Korean J Gastroenterol. 2014, 64:40-4. 10.4166/kjg.2014.64.1.40

13. Abukhalaf SA, Dandis BW, Za'tari T, Amro AM, Alzughayyar TZ, Rajabi YA: Familial mediterranean fever 


\section{Cureus}

complicated by a triad of adrenal crisis: amyloid goiter and cardiac amyloidosis. Case Rep Rheumatol. 2020, 2020:7865291. 10.1155/2020/7865291

14. Ceylan Ö, Ceylan Y: Intermittent right bundle branch block in a child with familial mediterranean fever Cardiol J. 2018, 25:753-5. 10.5603/CJ.2018.0154

15. El Hasbani G, Jawad A, Uthman I: Update on the management of colchicine resistant familial Mediterranean fever (FMF). Orphanet J Rare Dis. 2019, 14:224. 10.1186/s13023-019-1201-7 